\title{
HUBUNGAN REGULASI DIRI DENGAN KECEMASAN MENGHADAPI UJIAN SKRIPSI PADA MAHASISWA PROGRAM STUDI PENDIDIKAN EKONOMI UNIVERSITAS MUHAMMADIYAH PURWOREJO
}

\author{
Cahyana Nursidiq \\ Program Studi Pendidikan Ekonomi \\ Universitas Muhammadiyah Purworejo \\ cahya.umpwr@gmail.com
}

\begin{abstract}
The aim of this research is to find out the relationship between self-regulation and anxiety in facing thesis examination on the the students of Economics Education, Faculty of Teacher Training And Educational Sciences Muhammadiyah University of Purworejo. The research was conducted from January until June 2013 in Economics Education, Faculty of Teacher Training and Educational Sciences Muhammadiyah University of Purworejo. Method applied in this research was survey method. Fifty students are taken as respondents in which they are thesis examination takers on period 2 and 3 in 2013. Variables observed are selfregulation and anxiety in facing thesis examination. Data were analysed by using descriptive analysis and rank spearman. Questionares were examined by using validity and reliability validity. From the correation analysis result (r), it is obtained correlation between selfregulation and and anxiety in facing thesis examination as much as - 0,606. This result shows there is strong relationship between self-regulation and and anxiety in facing thesis examination. While relationship flow is negative because $r$ value is negative. This fact shows high self-regulation will result low anxiety in facing thesis examination.
\end{abstract}

Keywords : Self-Regulation, Anxiety, Thesis Examination

\begin{abstract}
Abstrak. Penelitian ini bertujuan untuk mengetahui hubungan regulasi diri dengan kecemasan menghadapi ujian skripsi pada mahasiswa Program Studi Pendidikan Ekonomi Universitas Muhammadiyah Purworejo. Penelitian dilaksanakan mulai Januari sampai dengan Juni 2013 di Program Studi Pendidikan Ekonomi Universitas Muhammadiyah Purworejo. Metode yang digunakan dalam penelitian ini yaitu metode survai. Responden diambil sebanyak 15 orang yang merupakan peserta ujian skripsi periode 2 dan 3 tahun 2013. Variabel yang diamati dalam penelitian ini yaitu regulasi diri dan kecemasan menghadapi ujian skripsi. Data dianalisis menggunakan analisa deskriptif dan korelasi rank spearman. Kuesioner diuji dengan analisis validitas dan reliabilitas. Dari hasil analisis korelasi (r) didapat korelasi antara regulasi diri dengan kecemasan menghadapi ujian skripsi (r) adalah - 0,606. Hal ini menunjukkan bahwa terjadi hubungan yang kuat antara regulasi diri dengan kecemasan menghadapi ujian skripsi. Sedangkan arah hubungan adalah negatif karena nilai $r$ negatif, hal ini menunjukan semakin tinggi regulasi diri dalam pembelajaran maka semakin menurunkan kecemasan dalam menghadapi ujian skripsi.
\end{abstract}

Kata Kunci: Regulasi Diri, Kecemasan, Ujian Skripsi

\section{PENDAHULUAN}

Mahasiswa sebagai salah satu instrumen penting dari perguruan tinggi perlu mempersiapkan diri dan menjalankan perannya dengan semaksimal mungkin. Salah satu indikator keberhasilan mahasiswa dalam menjalankan perannya 
adalah dengan menyelesaikan studi sesingkat mungkin disertai dengan hasil studi yang memuaskan.

\section{Dalam proses belajar, seorang} mahasiswa dituntut untuk memilki kemandirian dalam belajar. Kemandirian tersebut dapat ditunjukkan dengan cara mengorganisasikan seluruh kegiatan pembelajaran yang akan dilakukan. Mahasiswa yang dapat mengatur proses pembelajaran mereka akan cenderung lebih berhasil dalam meningkatkan prestasi akademis mereka. Dengan adanya kemampuan mengorganisir keterampilan metakognitif, dan mampu memotivasi diri serta memanfaatkan lingkungan belajar, mahasiswa akan cenderung lebih berhasil dalam proses pembelajaran. Untuk menunjang hal tersebut, diperlukan kemampuan dalam mengatur dirinya sendiri. Kemampuan inilah yang disebut dengan regulasi diri, yaitu usaha individu untuk mengatur diri dengan menggunakan kemampuannya secara aktif dalam kegiatan belajar.

Zimmerman (dalam Anita Woolfolk, 2006) menjelaskan "regulasi diri sebagai proses yang kita gunakan untuk mengaktifkan dan mempertahankan pikiran, perilaku, dan emosi kita untuk mencapai tujuan kita". Lebih lanjut Zimmerman (dalam Catherine S. Chen, 2002) mendefinisikan "self-regulated learners are individuals who are metacognitively, motivationally, and behaviorally active participants in their own learning process". (regulasi diri adalah siswa yang secara metakognitif, motivasional dan behavioral merupakan peserta aktif dalam proses belajar mereka sendiri). Senada dengan hal tersebut Elizabeth A. Jordon, Marian J. Poratt (2006) menjelaskan "self-regulated learning includes effective strategies for learning, reflection on one's own thinking and learning (metacognition), and motivation and engagement with school tasks". (pembelajaran regulasi-diri merupakan bagian dari strategi yang efektif untuk belajar, merefleksi pada satu cara berpikir dan belajar (metakognisi), memotivasi dan melibatkan tugas-tugas di sekolah).

Dari sudut proses metakognitif, selfregulated learner melakukan perencanaan, pengorganisasian, instruksi diri dan evaluasi diri pada berbagai tingkat selama proses penguasaan materi pelajaran. Dari sisi motivasional, self-regulated learner memandang diri mereka sendiri sebagai memiliki cukup self-efikasi, otonom, dan termotivasi secara intrinsik. Dari sisi perilaku, self-regulated learner memilih, menstruktur, dan bahkan menciptakan lingkungan sosial dan lingkungan fisik untuk mengoptimalisasikan penguasaan mereka atas materi pelajaran. Menurut sudut pandang ini, siswa yang efektif menjadi sadar akan relasi fungsional antara pola pikir dan tindakan mereka (sering disebut sebagai strategi) dan hasil-hasil sosial dan lingkungan (Zimmerman \& Martinez-Pons, dalam Nugraha Arif Karyanta, 2002).

Regulasi diri adalah siswa yang secara metakognitif, motivasional dan behavioral merupakan peserta aktif dalam proses belajar mereka sendiri. Dari sisi motivasional, Self-Regulated Learner memandang diri mereka sendiri sebagai memiliki cukup self-efikasi, otonom, dan termotivasi secara intrinsik. Dari sisi perilaku, Self-Regulated Learner memilih, menstruktur, dan bahkan menciptakan lingkungan sosial dan lingkungan fisik untuk mengoptimalisasikan penguasaan mereka atas materi pelajaran (Cahyana Nursidiq, 2011).

Tahap akhir bagi seorang mahasiswa mampu menyelesaikan studi adalah kemampuan mereka untuk menyelesaikan tugas akhir atau skripsi. Skripsi merupakan suatu istilah yang umum digunakan untuk suatu karya ilmiah berupa paparan hasil penelitian mahasiswa untuk mendapatkan gelar sarjana yang membahas suatu permasalahan atau fenomena dengan 
menggunakan kaidah yang berlaku. Mahasiswa yang mampu menyelesaikan skripsi dianggap telah mampu memadukan pengetahuan dan keterampilannya dalam memahami, menganalisis, menggambarkan serta menjelaskan masalah yang berhubungan dengan bidang keilmuan yang diambilnya.

Tahap akhir dari penyusunan skripsi adalah ujian skripsi. Ujian ini sekaligus menjadi penentu kelulusan mahasiswa dalam menyelesaikan studinya di tingkat perguruan tinggi dan mencapai gelar sarjana. Tolok ukur inilah yang seringkali menimbulkan ketakutan dan kekhawatiran tersendiri bagi mahasiswa akan bayangbayang akan kegagalan dalam mempertahankan hasil penelitian tersebut dihadapan penguji skripsi. Keadaan ini menimbulkan kecemasan tersendiri sehingga tidak sedikit mahasiswa sengaja menunda ujian skripsi meskipun naskah atau materinya telah dinyatakan siap uji atau presentasi. Bayangan akan sulitnya pernyataan dalam proses ujian memunculkan perasaan takut akan gagal, rasa cemas yang berlebihan, dan berbagai respon tidak menyenangkan lainnya. Sehingga tidak jarang dijumpai banyak mahasiswa yang menunda untuk segera menyelesaikan skripsi karena bayangbayang akan sulitnya menjawab pertanyaan-pertanyaan penguji pada waktu ujian skripsi dilakukan.

Kemampuan mahasiswa dalam meregulasi pembelajaran akan mengurangi kecemasan mahasiswa dalam menghadapi ujian skripsi. Mahasiswa yang siap secara kognitif, motivasional dan behavioral akan lebih percaya diri dalam proses belajar. Oleh karena itu dalam penelitian ini akan dicari sejauh mana hubungan regulasi diri akan mampu untuk menurunkan tingkat kecemasan dalam menghadapi ujian skripsi.

Kecemasan yang dialami seseorang dapat diketahui melalui gejala-gejala yang muncul. Supratiknya mengungkapkan beberapa gejala kecemasan, yakni selalu diliputi rasa tegang, was-was, resah, perasaan tidak menentu, peka/mudah tersinggung, minder, merasa tidak mampu, depresi, serba salah, sulit konsentrasi, bereaksi berlebihan, otototot terasa tegang, mimpi buruk, sering buang air kecil, insomnia, banyak berkeringat, gangguan pernafasan tanpa sebab, dan mengalami anxiety attack tanpa sebab yang jelas.

Gejala-gejala tersebut oleh Daradjat (1990) diaktegorikan dalam dua bentuk gejala yakni: (1) gejala fisiologis yang berupa peningkatan kecepatan detak jantung, keringat berlebihan, tidur tidak nyenyak, nafsu makan menghilang, sesak nafas, sakit lambung tiba-tiba dan gelaja fisik lainnya; (2) gejala psikologis meliputi perasaan takut, was-was akan mengalami kecelakaan atau peristiwa yang mengancam, sulit memusatkan perhatian, tidak berdaya, rendah diri, menurunkan kepercayaan diri dan khawatir akan gagal.

Dari beberapa penjelasan tersebut diatas, dapat disimpulkan bahwa gejala kecemasan yang dapat muncul akibat menghadapi ujian skripsi adalah gejala fisiologis dan psikologis yang tidak menyenangkan yang disebabkan oleh ketidaksiapan menghadapi ujian skripsi.

Skripsi sebagai salah satu syarat seorang mahasiswa menyelesaikan studi, sering kali dianggap sebagai momok yang menakutkan bagi setiap mahasiswa dalam menyelesaikan studi. Kemampuan mahasiswa dalam meregulasi pembelajaran akan mengurangi kecemasan mahasiswa dalam menghadapi ujian skripsi. Mahasiswa yang siap secara kognitif, motivasional dan behavioral akan lebih percaya diri dalam proses belajar. Dari hal tersebut, dapat dirumuskan permasalahan sebagai berikut: "Apakah terdapat hubungan antara regulasi diri dengan kecemasan menghadapi ujian skripsi pada mahasiswa program studi pendidikan 
ekonomi Universitas Muhammadiyah Purworejo?"

\section{METODOLOGI PENELITIAN}

Penelitian ini dilaksanakan di Program Studi Pendidikan Ekonomi, Fakultas Keguruan Dan Ilmu Pendidikan, Universitas Muhammadiyah Purworejo Jl. KH. Ahmad Dahlan No. 4 Purworejo. Populasi dalam penelitian ini adalah mahasiswa tingkat akhir Program Studi Pendidikan Ekonomi, FKIP, Universitas Muhammadiyah Purworejo yang akan menghadapi ujian skripsi. Aspek-aspek yang diungkapkan dalam penelitian ini adalah regulasi diri, dan kecemasan menghadapi ujian skripsi.

Penelitian ini termasuk dalam kelompok penelitian deskriptif kuantitatif. Moh. Nazir (1999) mengemukakan bahwa "penelitian deskriptif adalah studi untuk menemukan fakta dengan interpretasi yang tepat". Penelitian deskriptif berusaha untuk melukiskan secara akurat sifat-sifat dari beberapa fenomena, kelompok atau individu. Tujuan dari penelitian deskriptif adalah untuk membuat deskripsi gambaran atau lukisan secara sistematis, faktual dan akurat mengenai fakta-fakta, sifat-sifat serta hubungan antar fenomena yang diselidiki. Metode yang digunakan dalam penelitian ini adalah metode penelitian kuantitatif dengan pendekatan korelasional. "Penelitian korelasi bertujuan untuk menemukan ada tidaknya hubungan dan apabila ada, berapa eratnya hubungan serta berarti atau tidak hubungan itu". (Suharsimi Arikunto, 2002).

\section{Definisi Operasional Variabel Penelitian}

1. Variabel Bebas

$$
\text { Regulasi diri dalam }
$$

pembelajaran

(Self-Regulated

Learning) merupakan proses atau perilaku belajar yang secara aktif melibatkan kemampuan metakognitif, motivasional dan behavioral siswa. Keterlibatan secara aktif dalam proses belajar meningkatkan performansi akademik mereka. Tingkat regulasi diri subjek diketahui dengan skor yang diperoleh subjek setelah mengisi skala regulasi diri. Semakin tinggi skor yang diperoleh, semakin tinggi kemampuan meregulasi pembelajaran. Semakin rendah skor yang diperoleh, semakin rendah kemampuan meregulasi pembelajaran.

2. Variabel Tergantung

Kecemasan menghadapi ujian skripsi adalah keadaan emosi yang tidak stabil atau tidak menyenangkan dan disertai reaksi fisik atau tubuh akibat ketidaksipan menghadapi ujian skripsi. Tingkat kecemasan menghadapi ujian skripsi diketahui dengan skor yang diperoleh subjek setelah mengisi skala kecemasan menghadapi ujian skripsi. Semakin tinggi skor yang diperoleh, semakin tinggi kecemasan dalam menghadapi ujian skripsi. Semakin rendah skor yang diperoleh, semakin rendah kecemasan dalam menghadapi ujian skripsi.

\section{HASIL PENELITIAN}

\section{A. Deskripsi Data}

Dalam penelitian ini terdapat dua variabel yang akan diteliti, yaitu variabel bebas dan satu variabel terikat. Adapun variabel-variabel tersebut adalah:

1. Regulasi diri dalam pembelajaran (X).

2. Kecemasan dalam menghadapi ujian skripsi (Y).

Data variabel tersebut diperoleh dengan teknik angket. Teknik angket digunakan untuk memperoleh data mengenai regulasi diri dalam pembelajaran dan kecemasan menghadapi ujian skripsi. Data yang telah terkumpul melalui proses pengumpulan data dapat dideskripsikan sebagai berikut: 
1. Regulasi Diri Dalam Pembelajaran (X)

Data tentang regulasi diri dalam pembelajaran diperoleh dari skor hasil pengolahan data angket yang telah diisi oleh mahasiswa Program Studi Pendidikan Ekonomi yang ujian skripsi periode ke dua dan ke tiga pada tanggal 4 Juni 2013 dan 8 Juni 2013. Berdasarkan hasil perhitungan yang telah dilakukan, dapat dibuat tabel distribusi frekuensi sebagai berikut:

Tabel 1. Distribusi Frekuensi Variebel Regulasi Diri

\begin{tabular}{|c|c|c|}
\hline $\begin{array}{c}\text { Interval } \\
\text { Kelas }\end{array}$ & Frekuensi & $\begin{array}{c}\text { Frekuensi } \\
\text { Komulatif } \%\end{array}$ \\
\hline $45-52$ & 4 & $26,67 \%$ \\
\hline $53-60$ & 5 & $60,00 \%$ \\
\hline $61-68$ & 3 & $80,00 \%$ \\
\hline $69-76$ & 1 & $86,67 \%$ \\
\hline $77-84$ & 2 & $100,00 \%$ \\
\hline Jumlah & 15 & $100,00 \%$ \\
\hline
\end{tabular}

Berdasarkan tabel tersebut dapat diketahui bahwa banyak kelas yang ditetapkan dalam penelitian ini terdiri dari 5 kelas dengan interval kelas 8. Data regulasi diri yang berasal dari angket ini menyebar dari skor terendah 47 dan tertinggi 84. Rentangan skor yang muncul adalah $(87$ - 47) $=37$. Data gaya kepemimpinan transformasional guru dengan frekuensi tertinggi berada pada interval 53-60, dan yang terendah pada interval 69-76. Angka-angka tersebut kemudian dianalisis dan hasilnya adalah sebagai berikut:
a. Mean
$=61,73$
b. Median
$=59$
c. Modus
$=51$
d. Standart Deviasi $=10,9$

2. Kecemasan Dalam Menghadapi Ujian Skripsi (Y)

Data tentang kecemasan dalam menghadapi ujian skripsi diperoleh dari skor hasil pengolahan data angket yang telah diisi oleh mahasiswa Program Studi Pendidikan Ekonomi yang ujian skripsi periode ke dua dan ke tiga pada tanggal 4 Juni 2013 dan 8 Juni 2013. Berdasarkan hasil perhitungan yang telah dilakukan, dapat dibuat tabel distribusi frekuensi sebagai berikut:

Tabel 2. Distribusi Frekuensi Variebel Kecemasan

\begin{tabular}{|c|c|c|}
\hline Interval Kelas & Frekuensi & $\begin{array}{c}\text { Frekuensi } \\
\text { Komulatif \% }\end{array}$ \\
\hline $30-34$ & 4 & $26,67 \%$ \\
\hline $35-39$ & 2 & $40,00 \%$ \\
\hline $40-44$ & 2 & $53,33 \%$ \\
\hline $45-49$ & 1 & $60,00 \%$ \\
\hline $50-54$ & 6 & $100,00 \%$ \\
\hline Jumlah & 15 & $100,00 \%$ \\
\hline
\end{tabular}

Berdasarkan tabel tersebut dapat diketahui bahwa banyak kelas yang ditetapkan dalam penelitian ini terdiri dari 5 kelas dengan interval kelas 5. Data regulasi diri yang berasal dari angket ini menyebar dari skor terendah 30 dan tertinggi 53. Rentangan skor yang muncul adalah $(53-30)=23$. Data gaya kepemimpinan transformasional guru dengan frekuensi tertinggi berada pada interval 50 - 54, dan yang terendah pada interval 45 - 49. Angka-angka tersebut kemudian dianalisis dan hasilnya adalah sebagai berikut:
a. Mean
$=42,93$
b. Median
$=43$
c. Modus
$=50$
d. Standart Deviasi $=8,45$

\section{B. Pengujian Persyaratan Analisis}

Sebelum data dianalisis, maka data tersebut terlebih dahulu harus melalui tahap pengujian prasyarat analisis sebagai berikut:

\section{Uji Normalitas}

Uji normalitas digunakan untuk mengetahui apakah sampel 
diambil dari populasi yang berdistribusi normal atau tidak. Uji Normalitas dalam penelitian ini dilakukan dengan menggunakan uji Kolmogorov-Smirnov. Pedoman pengambilan keputusan untuk uji normalitas Kolmogorov-Smirnov adalah sebagai berikut:

- Jika probabilitas > 0,05, maka $\mathrm{H}_{\mathrm{o}}$ diterima.

- Jika probabilitas < 0,05, maka $\mathrm{H}_{\mathrm{o}}$ ditolak.

Hasil uji normalitas regulasi diri menunjukan sebaran variabel sebesar 0,628 atau probabilitas di atas $0,05(0,628>0,05)$. Maka $\mathrm{H}_{\mathrm{o}}$ diterima, atau regulasi diri berdistribusi normal. Sedangkan hasil untuk uji normalitas kecemasan dalam menghadapi ujian skripsi menunjukan sebaran variabel sebesar 0,595 atau probabilitas di atas $0,05(0,595>$ 0,05). Maka $\mathrm{H}_{0}$ diterima, atau variabel kecemasan menghadapi ujian skripsi berdistribusi normal.

\section{Uji Linieritas}

Uji linieritas diperlukan untuk mengetahui apakah data yang akan dianalisis merupakan data yang berbentuk regresi linier. Dari hasil perhitungan diperoleh data sebagai berikut:

Dari data deviation from liniarity diketahui bahwa signifikansi > $(0,05)$ atau $0,891>$ $(0,05)$. Sehingga dapat kita interpretasikan bahwa hubungan kedua variabel tersebut linier signifikan.

\section{Pengujian Hipotesis}

\section{Analisis Data}

a. Hubungan Antara Regulasi Diri dan Kecemasan Menghadapi Ujian Skripsi

Untuk menguji hipotesis "ada hubungan yang signifikan antara regulasi diri dan kecemasan menghadapi ujian skripsi” digunakan teknik analisis korelasi Product Moment Spearmen.

Tabel 3. Hasil Uji Hipotesis

Correlations

\begin{tabular}{|c|c|c|c|c|}
\hline & & & Regulasi Diri & Kecemasan \\
\hline \multirow[t]{6}{*}{ Spearman's rho } & Regulasi Diri & Correlation Coefficient & 1,000 & -606 \\
\hline & & Sig. (2-tailed) & & ,017 \\
\hline & & N & 15 & 15 \\
\hline & Kecemasan & Correlation Coefficient & $-606^{\prime}$ & 1,000 \\
\hline & & Sig. (2-tailed) &, 017 & \\
\hline & & $\mathrm{N}$ & 15 & 15 \\
\hline
\end{tabular}

* Correlation is significant at the 0.05 level (2-tailed)

Dari hasil analisis korelasi (r) didapat korelasi antara regulasi diri dengan kecemasan menghadapi ujian skripsi (r) adalah - 0,606. Hal ini menunjukkan bahwa terjadi hubungan yang kuat antara regulasi diri dengan kecemasan menghadapi ujian skripsi. Sedangkan arah hubungan adalah negatif karena nilai $r$ negatif, hal ini menunjukan semakin tinggi regulasi diri dalam pembelajaran maka semakin menurunkan kecemasan dalam menghadapi ujian skripsi.

\section{PEMBAHASAN}

Berdasarkan hasil analisis data dari penelitian yang telah dilakukan pada mahasiswa Program Studi Pendidikan Ekonomi Universitas Muhammadiyah Purworejo menunjukan terdapat hubungan negatif antara regulasi diri dengan kecemasan menghadapi ujian skripsi. Analisis data yang telah dilakukan berhasil membuktikan bahwa ada hubungan negatif antara regulasi diri dengan kecemasan menghadapi ujian skripsis. Dengan demikian, hipotesis tersebut dapat diterima, sehingga dapat dikatakan bahwa regulasi diri memiliki andil yang signifikan terhadap tingkat kecemasan mahasiswa dalam menghadapi ujian skripsi. Hasil analisis tersebut berhasil menunjukan bahwa terdapat hubungan antara regulasi diri dengan kecemasan menghadapi 
ujian skripsi dengan nilai $\mathrm{r}$ (koefisien korelasi) $r_{X_{1} Y}=-0,606$.

Hal ini menunjukan bahwa semakin baik regulasi diri dalam pembelajaran akan semakin menurunkan kecemasan seorang siswa dalam menghadapi ujian skripsi, begitu pula sebaliknya semakin rendah kemampuan seorang mahasiswa dalam meregulasi pembelajaran maka akan semakin tinggi tingkat kecemasan seorang mahasiswa dalam menghadapi ujian skripsi.

Ujian skripsi merupakan salah satu tahap akhir penyusunan skripsi atau tugas akhir untuk mencapai gelar sarjana. Ujian ini sekaligus menjadi penentu kelulusan mahasiswa dalam menyelesaikan studinya di tingkat perguruan tinggi. Tolok ukur inilah yang seringkali menimbulkan ketakutan dan kekhawatiran tersendiri bagi mahasiswa yang bersangkutan, sehingga saat semakin dekat dengan pelaksanaan ujian skripsi tersebut semakin tidak nyaman karena bayangan akan sulitnya pernyataan dan alotnya diskusi dalam proses tersebut. Tidak heran bila menjelang ujian, justru muncul perasaan takut akan gagal, rasa cemas yang berlebihan, dan berbagai respon tidak menyenangkan lainnya sehingga tidak sedikit mahasiswa sengaja menunda ujian skripsi meskipun naskah/materinya telah dinyatakan siap uji/presentasi.

Kemampuan mahasiswa dalam meregulasi proses pembelajarannya akan membawa dampak yang positif untuk menemukan cara atau strategi yang efektif dalam belajar, sebagai contoh, pebelajar tahu gaya pembelajaran yang lebih disukai (apa yang mudah dan sulit, bagaimana cara mengatasi bagian-bagian yang sulit, apa minat dan bakatnya, dan bagaimana cara memanfaatkan kekuatannya).

Mahasiswa yang mampu meregulasi pembelajaran akan merasa lebih memiliki kesiapan dalam menghadapi ujian skripsi. Rasa takut yang dihadapi akan bayangbayang sulitnya pertanyaan penguji hingga pada gagalnya hasil ujian skripsi akan semakin rendah apabila mahasiswa mampu meregulasi pembelajarannya dengan baik dalam menghadapi ujian skripsi tersebut.

\section{PENUTUP}

\section{SIMPULAN}

Berdasarkan analisis dan pembahasan hasil penelitian maka dapat diambil kesimpulan penelitian yaitu: Ada hubungan negatif dan signifikan antara regulasi diri dengan kecemasan menghadapi ujian skripsi pada mahasiswa Program Studi Pendidikan Ekonomi Universitas Muhammadiyah Purworejo. Artinya semakin baik atau positif mahasiswa dapat meregulasi diri dalam pembelajaran, maka akan semakin rendah tingkat kecemasan seorang mahasiswa dalam menghadapi ujian skripsi.

\section{SARAN}

Berdasarkan kesimpulan, maka dapat disampaikan saran-saran sebagai berikut:

1. Bagi Mahasiswa

Regulasi diri merupakan proses yang gunakan untuk mengaktifkan dan mempertahankan pikiran, perilaku, dan emosi kita untuk mencapai tujuan. Dalam proses belajar di Perguruan Tinggi, mahasiswa cenderung lebih otonom dalam proses pembelajarannya. Mahasiswa harus dapat mengatur kegiatan pembelajarannya sehingga ketakutanketakutan yang muncul dalam pembelajaran yang pada akhirnya menimbulkan kecemasan dapat diminimalisir. Mahasiswa yang memiliki kecemasan yang tinggi akan cenderung memiliki rasa takut yang berlebih akan bayang-bayang kegagalan dalam pembelajaran.

2. Bagi peneliti lain

Penelitian ini dapat digunakan sebagai referensi faktor yang mempengaruhi kecemasan mahasiswa dalam 
menghadapi ujian skripsi. Bagi peneliti lain yang berminat mengadakan penelitian serupa hendaknya dapat memperhatikan faktor-faktor lain yang mungkin berpengaruh terhadapa kecemasan mahasiswa dalam menghadapi ujian skripsi, misalnya lingkungan sosial, emosi, usia dan juga faktor-faktor lainnya.

\section{DAFTAR PUSTAKA}

Anita Woolfolk. 2009. Educational Psychology: Active Learning Edition. Yogyakarta: Pustaka Pelajar

Cahyana Nursidiq, Pengaruh Model Pembelajaran Self-Regulated Learning Terhadap Prestasi Belajar Ekonomi Ditinjau Dari Motivasi Belajar Siswa. Tesis (Tidak Diterbitkan). UNS

Catherine S. Chen. 2002. Self-Regulated Learning Strategies And Achievement In An Introduction To Information System Course. Information Technology, Learning, And Performance Journal, Vol 20, No. 1 , Spring, 2002

Daradjat, Z. 1990. Kesehatan Mental. Jakarta : CV Haji Masagung

Elizabeth A. Jordon, Marian J. Poratt. 2006. Educational Psychology: Problem-based Approach. Boston. Pearson Education, Inc.

Moh. Nasir. 1999. Metode Penelitian. Jakarta: Ghalia Indonesia.

Nugraha Arif Karyanta. 2002. Hubungan Persepsi gaya Kepemimpinan Transformasional Guru dengan Strategi Self-Regulated Learning Siswa. Skripsi (tidak diterbitkan). UGM
Suharsimi Arikunto. 2002. Prosedur Penelitian (Suatu Pendekatan Praktek). Jakarta: Rineka Cipta.

Supratiknya. 1995. Komunikasi Antar Pribadi: Tinjauan Psikologis. Yogyakarta: Kanisius. 